Pesq. Vet. Bras. 37(12):1380-1384, dezembro 2017

DOI: $10.1590 / \mathrm{S} 0100-736 \mathrm{X} 2017001200004$

\title{
False-negative reactions to the comparative intradermal tuberculin test for bovine tuberculosis ${ }^{1}$
}

\author{
Rudielle A. Rodrigues ${ }^{2}$, Ingrid I.F.S. Meneses ${ }^{3}$, Klaudia S.G. Jorge ${ }^{2}$, Márcio R. Silva ${ }^{5}$, \\ Lenita R. Santos ${ }^{4}$, Walter Lilenbaum ${ }^{6}$, Rodrigo N. Etges ${ }^{7}$ and Flábio R. Araújo ${ }^{4 *}$
}

\begin{abstract}
Rodrigues R.A., Meneses I.I.F.S., Jorge K.S.G., Silva M.R., Santos L.R., Lilenbaum W., Etges R.N. \& Araújo F.R. 2017. False-negative reactions to the comparative intradermal tuberculin test for bovine tuberculosis. Pesquisa Veterinária Brasileira 37(12):13801384. Embrapa Gado de Corte, Av. Rádio Maia 830, Campo Grande, MS 79106-550, Brazil. E-mail: flabio.araujo@embrapa.br

According to the Brazilian National Program for the Control and Eradication of Animal Brucellosis and Tuberculosis (PNCEBT), the routine tests for the diagnosis of bovine tuberculosis in the country are the simple intradermal tuberculin test (SITT) of the Ministry of Agriculture, Livestock and Food Supply (MAPA), the caudal fold test and the comparative intradermal tuberculin test (CITT). The latter is also used as a confirmatory test. A group of 53 animals from three dairy herds in a focal area for bovine tuberculosis, that were submitted to depopulation in the state of Rio Grande do Sul, were submitted to the CITT. Tissues were cultured and the resulting colonies were confirmed by PCR and DNA sequencing. Among the 53 animals analyzed using the CITT, 32 (60.4\%) were negative, 14 (26.4\%) were positive and seven (13.2\%) results were inconclusive. The CITT detected 11 of the 39 animals with culture-confirmed $M$. bovis infection as positive. Among the total of 14 uninfected animals based on cultures, the CBT detected eight as negative. Thus, the CITT demonstrated sensitivity of $28.2 \%$ and specificity of $57.1 \%$ for the population sampled. A total of 24/32 (75.0\%) of the animals with negative CITT results were culture positive (confirmed by PCR) and were considered false negatives based on the CITT. The maintenance of these false-negative animals in herds has serious implications for the control of the disease, since they can be a source of infection. The addition of complementary tests could help identify such animals and increase the odds of diagnostic success.
\end{abstract}

INDEX TERMS: False-negative reactions, tuberculosis, Mycobacterium bovis, Comparative Intradermal Tuberculin Test, bacteriological culture.

\footnotetext{
${ }^{1}$ Received on March 7, 2017.

Accepted for publication on April 14, 2017.

${ }^{2}$ Programa de Pós-Graduação em Ciências Veterinárias, Faculdade de Medicina Veterinária e Zootecnia (FAMEZ), Universidade Federal de Mato Grosso do Sul (UFMS), Avenida Senador Filinto Muller 2443, Cidade Universitária, Campo Grande, MS 79070-900, Brasil.

${ }^{3}$ Programa de Pós-Graduação em Biotecnologia e Biodiversidade da Região Centro-Oeste, Universidade Federal de Mato Grosso do Sul (UFMS), Avenida Costa e Silva s/n, Campo Grande, MS 79070-900, Brasil.

${ }^{4}$ Laboratório de Imunologia, Sanidade Animal, Embrapa Gado de Corte, Avenida Rádio Maia 830, Zona Rural, Campo Grande, MS 70106-550, Brasil. *Corresponding author: flabio.araujo@embrapa.br

${ }^{5}$ Embrapa Gado de Leite, Rua Eugênio do Nascimento 610, Dom Bosco, Juiz de Fora, MG 36038-330, Brasil.

${ }^{6}$ Laboratório de Bacteriologia Veterinária, Universidade Federal Fluminense (UFF), Rua Hernani Mello 101, Sala 309, Niterói, RJ 24210-130, Brasil.

${ }^{7}$ Secretaria da Agricultura, Pecuária e Irrigação, Avenida Getúlio Vargas 1384, Menino Deus, Porto Alegre, RS 90150-004, Brasil.
}

RESUMO-- [Reações falso-negativas ao teste cervical comparativo para tuberculose bovina.] No Brasil, segundo o Programa Nacional de Controle e Erradicação da Brucelose e Tuberculose Animal (PNCEBT), do Ministério da Agricultura, Pecuária e Abastecimento (MAPA), os testes de rotina para o diagnóstico de tuberculose bovina são o teste cervical simples (TCC), o teste da prega caudal (TPC) e o teste cervical comparativo (TCC), sendo que o último também é utilizado como teste confirmatório. Um grupo de 53 animais oriundos de três rebanhos leiteiros de área de foco para tuberculose bovina que foram submetidos a vazio sanitário no Rio Grande do Sul foi submetido ao TCC. Os tecidos destes animais foram cultivados e as colônias resultantes confirmadas por PCR e sequenciamento de DNA. Dos 53 animais analisados no TCC, $32(60,4 \%)$ foram negativos, $14(26,4 \%)$ positivos e sete $(13,2 \%)$ inconclusivos, com 
base no PNCEBT. O TCC detectou como positivos 11 dos 39 animais com infecção por $M$. bovis confirmada por cultivo. Do total de 14 animais não infectados, baseado na cultura, o TCC detectou oito como negativos. Assim, o TCC apresentou, para a população amostrada, sensibilidade de $28,2 \%$ e especificidade de 57,1\%. Um total de 24/32 (75,0\%) dos animais negativos ao TCC foi positivo no cultivo (confirmado por PCR), sendo considerados falso-negativos ao TCC. A manutenção destes animais falso-negativos nos rebanhos tem sérias implicações para o controle da enfermidade, já que os mesmos podem ser fonte de infecção. A adição de testes complementares poderia auxiliar na identificação destes animais, aumentando a cobertura diagnóstica.

TERMOS DE INDEXAÇÃO: Reações falso-negativas, tuberculose bovina, Mycobacterium bovis, Teste Cervical Comparativo, cultura bacteriológica.

\section{INTRODUCTION}

Bovine tuberculosis (bTB) is a chronic infectious disease caused by the intracellular bacterium Mycobacterium bovis, which affects many domestic and wild species, especially cattle and buffalo, and causes disease in humans (Pesciaroli et al. 2014). The disease represents a threat to public health and causes economic losses, due mainly to the culling of infected cattle (Sa'idu et al. 2015). Moreover, the disease is a commercial barrier to the export of meat from Brazil (Brasil 2012).

In several countries, bTB control programs involve the detection and culling of infected animals based on the intradermal test, which measures the delay in hypersensitivity elicited by the inoculation of the mycobacterial antigen, denominated purified protein derivative (PPD). Although intradermal testing is the standard recommended method for the diagnosis of $M$. bovis infected animals (OIE 2015), there are concerns regarding its specificity due to cross-reactions with species of non-tuberculous mycobacteria (Chen et al. 2014). There are also limitations related to sensitivity due to the occurrence of animals in advanced stages of the disease, which become anergic (Whelan et al. 2011). Therefore, the consensus is that the intradermal test alone may not be able to detect all animals infected with $M$. bovis, leading to false-negative results (Casal et al. 2014, Mosavari et al. 2016).

Despite the success of programs for the control and eradication of bovine tuberculosis in several parts of the world, reports of persistent outbreaks of the disease remain frequent even after the implementation of such programs. This may be due to the reintroduction of infected cattle into herds, transmission by wild animals or a failure in detecting all infected animals, which can remain as reservoirs of TB (Conlan et al. 2012, Mosavari et al. 2016).

In Brazil, according to the National Program for the Control and Eradication of Animal Brucellosis and Tuberculosis (Programa Nacional de Controle e Erradicação da Brucelose e Tuberculose Animal - PNCEBT) of the Ministry of Agriculture, Livestock and Food Supply (MAPA), the recommended tests for the routine diagnosis of bTB are the simple intradermal tuberculin test (SITT), the caudal fold test (CFT) and the comparative intradermal tuberculin test (CITT). The latter is also used as a confirmatory test. Animals showing a difference in skin fold enhancement caused by inoculation of PPD from $M$. bovis (bPPD) and PPD from $M$. avium (aPPD) equal to or greater than $4 \mathrm{~mm}$ (bPPD - aPPD) are considered positive for tuberculosis (Brasil 2016). However, cross-reactions with environmental mycobacteria can sensitize animals, leading to positive results on the intradermal test even in the absence of tuberculous infection. Thus, it is also assumed that the peer evaluation of bPPD and aPPD responses would increase the specificity of the CITT and reduce the occurrence of false-positive reactions (Brasil 2006).

Although the CITT is considered a more specific test, it may have low sensitivity and not be able to identify truly infected animals (Whelan et al. 2011). In the present study, the occurrence of false-negative CITT reactions in infected dairy herds was tested. The occurrence of infection was demonstrated through the bacteriological culture of lesions suggestive of tuberculosis, followed by PCR and DNA sequencing of the resulting colonies. The impacts of the findings on the PNCEBT are discussed.

\section{MATERIALS AND METHODS}

Study design. This study was conducted between December 2014 and March 2015 with three dairy cattle herds from the municipalities of Arroio do Meio and Bom Retiro do Sul in the micro-region of Lajeado-Estrela in the state of Rio Grande do Sul, Brazil (Fig.1). A total of 53 animals from three herds were studied. All were of the Holstein breed and kept in a semi-intensive system. Regardless of the results of the intradermal test, all animals were slaughtered and submitted to necropsy, following the determination of the Official Veterinary Service of the state of Rio Grande do Sul to perform sanitary depopulation. Fragments of tissues and lymph nodes were cultured for mycobacteria. Colonies suggestive of $\mathrm{Myco}$ bacterium bovis were confirmed by PCR and DNA sequencing.

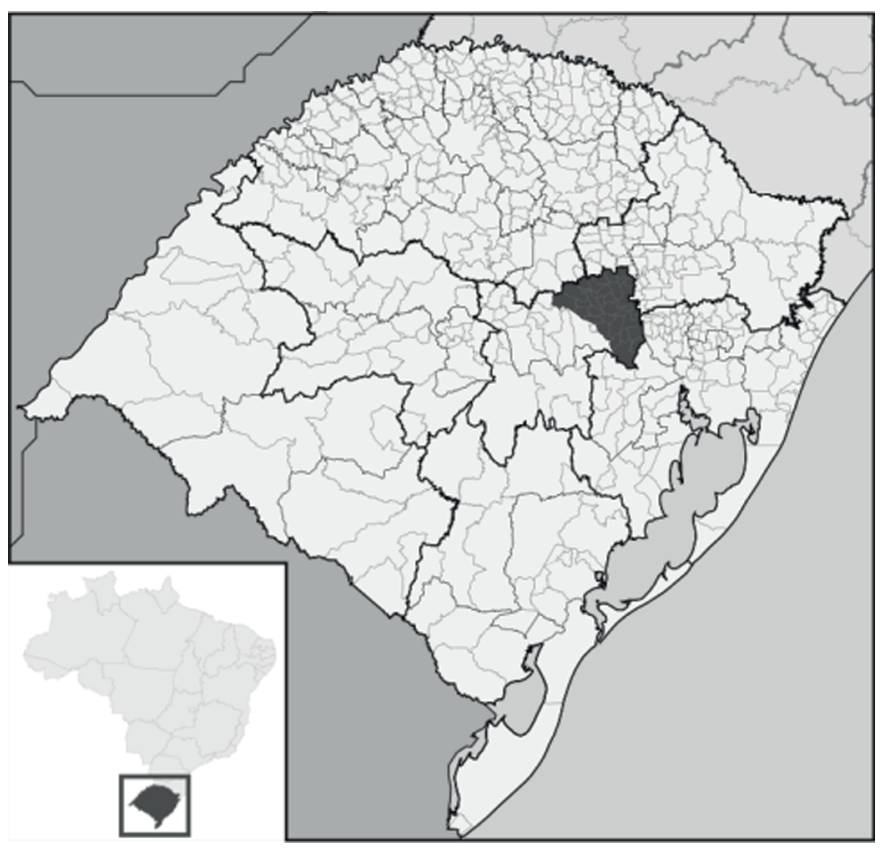

Fig.1. Lajeado-Estrela micro-region, state of Rio Grande do Sul, Brazil 
Herds and animals. Two of the three herds studied were accredited as being free of bTB: herd A since 2010 and herd B since 2013. Herd C was not accredited. In 2014, the routine intradermal test resulted in the detection of positive animals in the three herds, which were slaughtered. In 2015, the three herds were depopulated (38 animals in herd A, seven animals in herd B and eight animals in herd $\mathrm{C}$, totaling 53 animals).

Intradermal test. The CITT was performed according to the PNCEBT (Brasil 2016). The test consisted of an intradermal injection of $0.1 \mathrm{~mL}$ of bPPD and $0.1 \mathrm{~mL}$ aPPD, with a distance of 15 to $20 \mathrm{~cm}$ between both inoculations. The aPPD was infected cranially and bPPD was inoculated in the middle third of the cervical region. Readings were made after 72 hours using a cutimeter, with the evaluation of the delayed hypersensitivity reaction at the inoculation site. An animal was considered positive when the reaction to bPPD was greater than $4.0 \mathrm{~mm}$ compared to the reaction to aPPD. In compliance PNCEBT instructions, notifications of the reactive cattle were given to the Provinces of Agricultural Defense, which are the Local Units of Veterinary Service in the state of Rio Grande do Sul.

Samples. All animals from infected herds were slaughtered (depopulation) and submitted to necropsy. The animals were slaughtered under the supervision of the veterinary inspection service. Fragments of lung and mammary gland tissues as well as retropharyngeal, intramammary, pulmonary and mesenteric lymph nodes with or without macroscopic lesions compatible with tuberculosis (granulomas usually with a yellowish appearance and with a caseous, caseo-calcareous or calcified consistency) were collected from all animals. In the absence of lesions suggestive of tuberculosis, hepatic, mediastinal, mesenteric, retropharyngeal and tracheobronchial lymph nodes were collected. The tissue samples were placed separately in sealed plastic bags, indicating the number of the animal and the name of the organ collected. Screw cap vials were then immediately packed, each with two or three sets of tissues, indicating the numbers of the animals of the origin of the organ fragments. Immediately after collection, the samples were frozen for later shipment under refrigeration in a thermal insulation box, which was placed in a cardboard box indicating that it was an infective material, in compliance with the standards established by Packaging Instruction P/650-IATA (International Air Transport Association).

Culture and identification of Mycobacterium bovis. Tissue samples were kept frozen at $-30^{\circ} \mathrm{C}$ until processing. Fragments of perimetric tissues (between 10 and $25 \mathrm{mg}$ ) were macerated with $1.5 \mathrm{~mL}$ of sterile distilled water in a Magna Lyser apparatus (Roche Life Science), decontaminated using the Petroff method (Makovcova et al. 2015) and cultured in Stonebrink culture medium at $37^{\circ} \mathrm{C}$ for up to 90 days. Colonies suggestive of $M$. bovis were submitted to conventional PCR with primers Mb.400, which amplify a fragment with 400 base pairs (bp) flanking the region of differentiation 4 (RD4), which is absent in this species, but present in all the other members of the Mycobacterium tuberculosis Complex - MTC (Sales et al. 2014).

Purification of PCR products.- The amplicons were purified in a total reaction volume of $10 \mu \mathrm{L}$, each with $0.5 \mathrm{IU}$ of Shrimp Alkaline Phosphatase and 0.05 IU of Exonuclease I, and incubated at $37^{\circ} \mathrm{C}$ for 30 minutes, followed by $80^{\circ} \mathrm{C}$ for 20 minutes in a MJ Mini (Biorad) thermal cycler.

DNA sequencing. The DNA sequencing reactions were performed with the BigDye Terminator cycle sequencing kit (version 3.1, Applied Biosystems, Foster City, CA, USA) in a total reaction volume of $10 \mu \mathrm{L}$, with $1 \mu \mathrm{L}$ of DNA $(50 \mathrm{ng} / \mu \mathrm{L}), 5.8 \mathrm{uL}$ ultrapure water type $1.2 \mu \mathrm{L}$ of buffer, $0.5 \mu \mathrm{L}$ of $\mathrm{Mb} .400 \mathrm{R}$ primers $(5 \mathrm{mM})$ and $0.7 \mu \mathrm{L}$ of BigDye Terminator v3.1 Ready Reaction Mix. Amplifications were performed in a MJ Mini (Biorad) thermal cycler using the following program: $96^{\circ} \mathrm{C}$ for $1 \mathrm{~min}$, followed by 25 cycles of $96^{\circ} \mathrm{C}$ for $10 \mathrm{sec}, 50^{\circ} \mathrm{C}$ for $5 \mathrm{sec}$. and $60^{\circ} \mathrm{C}$ for $4 \mathrm{~min}$. A purification step was performed with EDTA (125mM, pH 8.0), 70\% ethanol and $100 \%$ ethanol. The purified PCR products were sequenced in an ABI-3130 automated sequencer (Applied Biosystems, USA).

Local alignment of DNA sequences. The base calling of the DNA sequences was performed with the Sequence Scanner program (Applied Biosystems) and the resulting DNA sequences were compared to the $\mathrm{nr} / \mathrm{nt}$ database bank by Blastn (https: // blast.ncbi.nlm.nih.gov/Blast.cgi).

Statistical analysis. The level of agreement between each two tests was assessed pairwise using McNemar's test or Fisher's exact tests, which determine whether or not paired proportions are different. The results were considered discordant when the test had a p-value $\leq 0.05$. Pearson's correlation coefficient was used to measure the degree of linear correlation between the two measures, obtained pairwise per animal: M. bovis and M. avium PPD.

\section{RESULTS}

In the analysis of the 53 cattle, the CITT detected 14 (26.4\%) positive animals and demonstrated seven $(13.2 \%)$ inconclusive results. At slaughter, lesions suggestive of tuberculosis (LST) were detected in organs/tissues of 43 animals, 13/14 animals with positive CITT (92.9\%), 5/7 inconclusive (71.4\%) and 25/32 (78.1\%) animals with negative CITT (Table 1). McNemar's test revealed a significant discrepancy between the CITT results and the presence of LST ( $p=0.000006468)$. For the paired odds ratio, the chance of discordant pairs of LST positive and CITT negative animals was 25 times (95\%CI: 3.38-184.5) the chance of LST negative and CITT positive animals.

Among the 53 animals studied, 39 (73.6\%) were confirmed as infected with $M$. bovis by bacteriological culture. Among the 43 animals in which tissues presented LST, 39 $(90.7 \%)$ were positive in the bacteriological culture, while all 10 animals without LST were negative. All the 39 animal culture positive presented LST. The CITT detected 11 of the 39 animals with culture-confirmed $M$. bovis infection. Among the total of 14 uninfected animals based on culture, the CITT detected eight as negative. Thus, CITT had sensitivity of $28.2 \%$ and specificity of $57.1 \%$. A total of $24 / 32$ (75.0\%) of the animals negative in the CITT were culture positive (confirmed by PCR) and were considered false-negatives (Table 1).

All colonies suggestive of $M$. bovis were confirmed by conventional PCR for RD4. Sequencing of the RD4 DNA fragment resulting from the $M$. bovis specific PCR was performed in 12/24 animals that had positive culture findings, but negative CITT findings. The resulting DNA sequen-

Table 1. Results of comparative intradermal cervical test (CITT), presence of lesions suggestive of tuberculosis (LST) and bacteriological culture of cattle from the LajeadoEstrela micro-region, Rio Grande do Sul, Brazil

\begin{tabular}{lccccc}
\hline CITT results & $\begin{array}{c}\text { LST +/ } \\
\text { culture }+\end{array}$ & $\begin{array}{c}\text { LST +/ } \\
\text { culture }-\end{array}$ & $\begin{array}{c}\text { LST - } \\
\text { culture }+\end{array}$ & $\begin{array}{c}\text { LST - / } \\
\text { culture- }\end{array}$ & Total \\
\hline CITT + & 11 & 2 & 0 & 1 & 14 \\
CITT - & 24 & 1 & 0 & 7 & 32 \\
CITT inconclusive & 4 & 1 & 0 & 2 & 7 \\
Total & 39 & 4 & 0 & 10 & 53
\end{tabular}


ces all presented the homologous fragment in the isolate AF2122/97of M. bovis (Sequence ID: LT708304), with identities of 99 to $100 \%$.

Fisher's exact test revealed no significant difference between the presence of LST and the occurrence of positive culture for $M$. bovis (one-tailed $\mathrm{p}=0.12$, two-tailed $\mathrm{p}=0.25$ ). The apparent prevalence of bTB in the herds studied was $26.4 \%$ based on the CITT, but the actual prevalence based on cultures confirmed by PCR was $73.6 \%$.

\section{DISCUSSION}

In Brazil, the only methods recommended by the National Program for the Control and Eradication of Brucellosis and Animal Tuberculosis (PNCEBT) for the antemortem diagnosis of bTB are the intradermal caudal fold test (CFT), simple intradermal tuberculin test (SITT) and cervical comparative tuberculin test (CITT). In the revision of the program, the latter test, which was previously considered a confirmatory test used on animals with inconclusive SITT results and reagents to CFT (Brasil 2006), was also considered a routine test (Brasil 2016).

M. bovis infection predominantly triggers a cell response in the initial and intermediate stages of infection coordinated by Th1 lymphocytes. Thus, intradermal PPD tests are based on the detection of this response (Schiller et al. 2010). The SITT detects the cellular response to bPPD, while CITT simultaneously tests the intradermal responses to bPPD and aPPD. Environmental mycobacteria can sensitize animals and therefore affect the results of intradermal tests by eliciting nonspecific reactions to bPPD (Aranaz et al. 2006, Aagaard et al. 2010) due to common antigens (Biet \& Boschiroli 2014). Thus, the CITT is expected to have greater specificity compared to the SITT in the diagnosis of bTB precisely because it detects possible cross-reactions to environmental mycobacteria. Most studies involving the slaughter of animals and bacteriological tissue cultures have shown that the CITT has adequate specificity (>90\%), with rates of 96 to $99 \%$ in the United Kingdom (UK) (Monaghan et al. 1994) and $98.6 \%$ in the USA (Farnham et al. 2012). Thus, there is consensus on the usefulness of CITT as a confirmatory method for $M$. bovis infection. With regard to the sensitivity of the CITT and its use as a screening method, the results are quite diverse. In a study conducted in the UK, which included postmortem examination of all animals in the herd, the sensitivity of CITT was 81\% (95\%CI: 70 to $89 \%$ ) (Karolemeas et al. 2012). The sensitivity of CITT is often reported to be unsatisfactory, with mean estimates of 68 to $90 \%$ in the UK (Monaghan et al. 1994) and an average of $88.4 \%$ in the USA (Farnham et al. 2012). Thus, the usefulness of the CITT as a screening method for $M$. bovis infection is questionable and should be recommended with caution.

Sanitary depopulations, in which the entire herd is slaughtered after failure to control bTB, are unique opportunities to evaluate quality parameters of intradermal tests, since positive and negative culture data are generated (Karolemeas et al. 2012). This strategy was used in the present study, allowing the comparison of intradermal reactions to PPD and bacterial cultures of LST, with molecular confirmation of the bacterial samples obtained. The CITT results diverged significantly from LST detection at slaughter, since LST was detected in several animals with negative CITT findings, characterizing false-negatives. The detection of LST did not differ significantly from the $M$. bovis culture, which lends support to the recommendation that slaughtered animals with suspected bTB should always be submitted to necropsy and carefully analyzed for LST (Araújo et al. 2014, Ejeh et al. 2014). It was not only possible to culture $M$. bovis from LST, but the colonies were confirmed by PCR, followed by DNA sequencing.

Despite the low number of cattle with inconclusive CITT results, most presented LST and $M$. bovis positive cultures, which lends support to the recommendation that animals with inconclusive results on farms with outbreaks of bTB may exhibit positive results with the progression of the disease and should be slaughtered (Zarden et al. 2013).

The main finding of the present study was that 25 (78\%) of the 32 animals with negative CITT results presented LST and all but one were confirmed by bacteriological cultures, which the standard method of diagnosis for bTB. This finding is alarming. If only the CITT had been applied to these herds, such animals would have been considered negative and would maintain the infection in the herd, spreading it to other animals and even humans. The spread of bTB to other regions may also occur, since infected animals could be sold with a certificate of negativity. It should be noted that two of the three herds examined had been accredited as bTB free. This situation may vary depending on the region studied and the CITT, although still an excellent confirmatory option in herds affected by environmental mycobacteria infections, was not confirmed in these herds as an adequate screening method for bTB.

The findings for the population studied are not necessarily extrapolatable to other epidemiological situations. In a recent study by our research group, only $1 / 51$ (1.9\%) animal with negative results had a positive culture for $M$. bovis (Araújo et al. 2014).

When a bovine is classified as negative by intradermal tests, there is no recommendation for additional tests in Brazil, even during an outbreak. Thus, such animals are often not slaughtered and further investigation is hampered by the difficulty in obtaining samples from live animals. Although attempts at direct diagnosis from live animal samples have been performed with nasal secretion (De Souza Figueiredo et al. 2010) and milk (Zarden et al. 2013, Bezerra et al. 2015), the results are not very encouraging.

The inability to identify all infected animals impairs the control and eradication of bTB (Lahuerta-Marin et al. 2016). In this study, the occurrence of a high percentage of false-negative CITT reactions led to the failure to control outbreaks and the indication of depopulation. The parallel use of different in vivo diagnostic tests, such as interferon-gamma for the detection of the cellular immune response (Marassi et al. 2010, Lahuerta-Marin et al. 2016), and serological tests, such as ELISA, for the detection of the humoral response (Marassi et al. 2011, Casal et al. 2014) may increase the diagnostic coverage of intradermal tests and reduce the impact of failed diagnoses on the control of bTB (Lahuerta-Marin et al. 2016). 


\section{CONCLUSIONS}

The CITT demonstrated low sensitivity in the diagnosis of bTB, leading to a high percentage of animals with false-negative reactions.

The maintenance of these false-negative animals in herds has serious implications for the control of the disease, since they can be a source of infection.

The addition of complementary tests could help identify such animals and increase the diagnostic coverage.

Acknowledgements.- To Ministério da Ciência, Tecnologia e Inovação (MCTI/CNPq/Universal, process 443235/2014-7), Fundect/CNPq (085/2015) and Embrapa (02.13.10.008.00.00). To Gisele Olivas de Campos Leguizamon, for the technical support and Carlos A.N. Ramos, for the revision of the manuscript.

\section{REFERENCES}

Aagaard C., Govaerts M., Meikle V., Gutiérrez-Pabello J.A., McNair J., Andersen P., Suárez-Güemes F., Pollock J., Espitia C. \& Cataldi A. 2010. Detection of bovine tuberculosis in herds with different disease prevalence and influence of paratuberculosis infection on PPDB and ESAT-6/CFP10 specificity. Prev. Vet. Med. 96:161-169.

Aranaz A., De Juan L., Bezos J., Alvarez J., Romero B., Lozano F., Paramio J.L., López-Sánchez J., Mateos A. \& Domínguez L. 2006. Assessment of diagnostic tools for eradication of bovine tuberculosis in cattle co-infected with Mycobacterium bovis and M. avium subsp. paratuberculosis. Vet. Res. 37:593-606.

Araújo C.P., Osório A.L., Jorge K.S., Ramos C.A., Filho A.F., Vidal C.E., Roxo E., Nishibe C., Almeida N.F., Júnior A.A., Silva M.R., Neto J.D., Cerqueira V.D., Zumárraga M.J. \& Araújo F.R. 2014. Detection of Mycobacterium bovis in bovine and bubaline tissues using nested-PCR for TbD1. PLoS One.9:1-6.

Biet F. \& Boschiroli M.L. 2014. Non-tuberculous mycobacterial infections of veterinary relevance. Res. Vet. Sci. 97:S69-77.

Brasil 2006. Programa Nacional de Controle e Erradicação da Brucelose e da Tuberculose Animal (PNCEBT). Departamento de Saúde Animal, Secretaria de Defesa Agropecuária, Ministério da Agricultura, Pecuária e Abastecimento (MAPA/SDA/DAS), Brasília, p.1-188.

Brasil 2012. Norma Interna SDA 02/2012. Secretaria de Defesa Agropecuária, Ministério de Agricultura, Pecuária e Abastecimento, Brasília, p.1-4.

Brasil 2016. Instrução Normativa $N^{\circ} 19$, de 10 de outubro de 2016. Secretaria de Defesa Agropecuária, Ministério de Agricultura, Pecuária e Abastecimento, Brasília, p.1-4.

Bezerra A.V., Dos Reis E.M., Rodrigues R.O., Cenci A., Cerva C. \& Mayer F.Q. 2015. Detection of Mycobacterium tuberculosis and Mycobacterium avium complexes by Real-Time PCR in bovine milk from Brazilian dairy farms. J. Food Prot. 78:1037-1042.

Casal C., Díez-Guerrier A., Álvarez J., Rodriguez-Campos S., Mateos A., Linscott R., Martel E., Lawrence J.C., Whelan C., Clarke J., O’Brien A., Domínguez L. \& Aranaz A. 2014. Strategic use of serology for the diagnosis of bovine tuberculosis after intradermal skin testing. Vet. Microbiol. 170:342-351.

Chen S., Parlane N.A., Lee J., Wedlock D.N., Buddle B.M. \& Rehm B.H. 2014. New skin test for detection of bovine tuberculosis on the basis of antigen-displaying polyester inclusions produced by recombinant Escherichia coli. Appl. Environ. Microbiol. 80:2526-2535.

Conlan A.J., McKinley T.J., Karolemeas K., Pollock E.B., Goodchild A.V., Mitchell A.P., Birch C.P., Clifton-Hadley R.S. \& Wood J.L. 2012. Estimating the hidden burden of bovine tuberculosis in Great Britain. PLoS Comput. Biol. 8:1-14.

De Souza Figueiredo E.E., Carvalho R.C.T., Silvestre F.G., Lilenbaum W., Fon- seca L.S., Silva J.T. \& Paschoalin V.M.F. 2010. Detection of Mycobacterium bovis DNA in nasal swabs from tuberculous cattle by a multiplex PCR. Braz. J. Microbiol. 41:386-390.

Ejeh E.F., Akinseye V.O., Igwe D., Adesokan H.K. \& Cadmus S.I. 2014. Molecular characterization of Mycobacterium bovis in slaughtered cattle in North-Central Nigeria and the public health implications. Afr. J. Med. Med. Sci. 43:97-104.

Farnham M.W., Norby B., Goldsmith T.J. \& Wells S.J. 2012. Meta-analysis of field studies on bovine tuberculosis skin tests in United States cattle herds. Prev. Vet. Med. 103:234-242.

Karolemeas K., de la Rua-Domenech R., Cooper R., Goodchild A.V., Clifton-Hadley R.S., Conlan A.J., Mitchell A.P., Hewinson R.G., Donnelly C.A., Wood J.L. \& McKinley T.J. 2012. Estimation of the relative sensitivity of the comparative tuberculin skin test in tuberculous cattle herds subjected to depopulation. PLoS One 7:1-7.

Lahuerta-Marin A., McNair J., Skuce R., McBride S., Allen M., Strain S.A., Menzies F.D., McDowell S.J. \& Byrne A.W. 2016. Risk factors for failure to detect bovine tuberculosis in cattle from infected herds across Northern Ireland (2004-2010). Res. Vet. Sci. 107:233-239.

Makovcova J., Babak V., Slany M. \& Slana I. 2015. Comparison of methods for the isolation of mycobacteria from water treatment plant sludge. Antonie van Leeuwenhoek 107:1165-1179.

Marassi C.D., Medeiros L. \& Lilenbaum W. 2010. The use of a Gamma-Interferon assay to confirm a diagnosis of bovine tuberculosis in Brazil. Acta Trop. 113:199-201.

Marassi C.D., Medeiros L., McNair J. \& Lilenbaum W. 2011. Use of recombinant proteins MPB70 or MPB83 as capture antigens in ELISAs to confirm bovine tuberculosis infections in Brazil. Acta Trop. 118:101-104.

Monaghan M.L., Doherty M.L., Collins J.D., Kazda J.F. \& Quinn P.J. 1994. The tuberculin test. Vet. Microbiol. 40:111-124.

Mosavari N., Geravand M.M., Tadayona K. \& Keshavarz R. 2016. Mycobacterial coinfection and persisting bovine tuberculosis - Has the time arrived for a policy review? Int. J. Mycobacteriol. 5:S82-S83

OIE 2015. Bovine Tuberculosis: manual of diagnostic tests and vaccines for terrestrial animals 2016. chapter. 2.4.6, World Organization for Animal Health, 1:1-17. Available at <http://www.oie.int/fileadmin/Home/ eng/Health_standards/tahm/2.04.06_BOVINE_TB.pdf> Acesso on May 6, 2016.

Pesciaroli M., Alvarez J., Boniotti M.B., Cagiola M., Di Marco V., Marianelli C., Pacciarini M. \& Pasquali P. 2014 Tuberculosis in domestic animal species. Res. Vet. Sci. 97:S78-S85.

Sales M.L., Fonseca A.A. Jr., Sales E.B., Cottorello A.C., Issa M.A., Hodon M.A., Soares Filho P.M., Ramalho A.K., Silva M.R., Lage A.P. \& Heinemann M.B. 2014. Evaluation of molecular markers for the diagnosis of Mycobacterium bovis. Folia Microbiol. 59:433-438.

Sa'idu A.S., Okolocha E.C., Dzikwi A.A., Gamawa A.A., Ibrahim S., Kwaga J.K.P., Usman A. \& Maigari S.A. 2015. Public health implications and risk factors assessment of Mycobacterium bovis infections among abattoir personnel in Bauchi state, Nigeria. J. Vet. Med. 2015:1-5.

Schiller I., Oesch B., Vordermeier H.M., Palmer M.V., Harris B.N., Orloski K.A., Buddle B.M., Thacker T.C., Lyashchenko K.P. \& Waters W.R. 2010. Bovine tuberculosis: a review of current and emerging diagnostic techniques in view of their relevance for disease control and eradication. Transbound Emerg. Dis. 57:205-20.

Whelan C., Shuralev E., Kwok H.F., Kenny K., Duignan A., Good M., Davis W.C. \& Clarke J. 2011. Use of a multiplex enzyme-linked immunesorbent assay to detect a subpopulation of Mycobacterium bovis-infected animals deemed negative or inconclusive by the single intradermal comparative tuberculin skin test. J. Vet. Diagn. Invest. 23:499-503.

Zarden C.F., Marassi C.D., Figueiredo E.E. \& Lilenbaum W. 2013 Mycobacterium bovis detection from milk of negative skin test cows. Vet. Rec. 172:130. 